\title{
Potential use of probiotic- and triherbal extract-enriched diets to control Aeromonas hydrophila infection in carp
}

\author{
Ramasamy Harikrishnan ${ }^{1}$, Chellam Balasundaram ${ }^{2}$, Moon-Soo Heo ${ }^{1, *}$ \\ ${ }^{1}$ Marine and Environmental Research Institute, Marine Applied Microbes and Aquatic Organism Disease Control Laboratory, \\ Department of Aquatic Biomedical Sciences, School of Marine Biomedical Sciences, College of Ocean Sciences, Jeju National \\ University, Jeju 690-756, South Korea \\ ${ }^{2}$ Department of Animal Science, Bharathidasan University, Tiruchirapalli-620 024, Tamilnadu, India
}

\begin{abstract}
This study reports the effect of probiotic- and triherbal extract-enriched diet on Cyprinus carpio $(52 \pm 2 \mathrm{~g}, \mathrm{n}=250)$ inoculated intramuscularly $(50 \mu \mathrm{l})$ with Aeromonas hydrophila $(1.8 \times$ $10^{6} \mathrm{CFU} \mathrm{m}{ }^{-1}$ ). On Day 6 post-infection, the fish were divided into 4 groups and fed with the basal diet (IU) or with diets supplemented with triherbal extract (H), Sporolac (S) or Lactobacillus (L). A fifth group of non-infected fish fed with the basal diet was used as a control. Haematology and immunology parameters were measured in Weeks 1, 2 and 4 . In the $\mathrm{H}, \mathrm{S}$, and L groups, white blood cell levels were significantly increased $(p<0.05)$ throughout the experimental period. In the $\mathrm{H}$ and $\mathrm{S}$ groups, red blood cell and haemoglobin levels decreased significantly $(p<0.05)$ in Weeks 1,2 and 4 . In all the diet groups, the haematocrit and mean corpuscular volume did not differ significantly $(p>0.05)$ in Week 1 , and these values remained near those of the control in Week 2 . The S and L groups did not exhibit significant changes ( $p>0.05$ ) in glucose, and cholesterol levels in Weeks 2 and 4 compared to controls, and the L group also showed no change in total protein. Respiratory burst activity was significantly increased in Weeks 1 to 4 in the H, S and L groups. Serum-mediated killing of Escherichia coli was significantly increased in the L group in Weeks 1 to 4 . Mortalities after A. hydrophila challenge were higher in the IU ( $85 \%)$ and $\mathrm{H}(50 \%)$ groups than in the S (45\%) and L (35\%) groups. Our results show that formulated probiotic-enriched diets can speed up the recovery of ulcerative dermatitis induced by A. hydrophila in carp.
\end{abstract}

KEY WORDS: Aeromonas hydrophila $\cdot$ Cyprinus carpio $\cdot$ Haematology $\cdot$ Triherbal extract $\cdot$ Probiotics Resale or republication not permitted without written consent of the publisher

\section{INTRODUCTION}

Common carp Cyprinus carpio is a species of global importance, not only because of its aesthetic value, but also due to its immense commercial value in the export trade. Aeromonas hydrophila is an opportunistic Gramnegative pathogen and causes an ulcerative condition, called motile aeromonad septicaemia (MAS), in wild and cultured fish (Leung et al. 1995). The bacterium causes various disease conditions in freswater fish, such as haemorrhagic septicaemia, infectious abdominal dropsy, and fin and tail rot (Austin \& Austin 1993). Diseased fish can be assessed through microbiological, histological and molecular techniques, such as polymerase chain reaction (PCR) analysis and enzyme-linked immunosorbent assay (ELISA). How- ever, these methods are expensive and occasionally time consuming (Chen et al. 2003). Historically, studies have used haematological indices and immunological assays to determine the health status of fish (Harikrishnan et al. 2003, 2009).

In order to improve the efficiency of feed utilization of finfish and shellfish, a number of feed additives, including both prophylactics and growth promoters, have been tested. However, this practice has several negative aspects, such as accumulation of antibiotic residues in the tissues that results in consumer reluctance (Ringø $\&$ Birkbeck 1999). Hence, management of fish diseases, except those for which vaccines are available, continues to be a challenging problem (Anderson 1992).

One promising method of controlling infection in aquaculture is strengthening the defence mechanisms 
of fish through prophylactic administration of probiotics and herbs (Gibson et al. 1997, Harikrishnan et al. 2003, 2010, Sharifuzzaman \& Austin 2009). Probiotics such as lactic acid bacteria, produce specific compounds such as bacteriocins or bacteriostatic peptides (Klaenhammer 1988) that inhibit the growth of fish pathogens, including Aeromonas hydrophila, Vibrio anguillarum and A. salmonicida (Lewus et al. 1991, Gildberg et al. 1995, Santos et al. 1996), in addition to improving water quality (Skjermo \& Vadstein 1999).

In India, as many as 500 medicinal plants have been used to treat various diseases of humans and animals (Vaidyaratnam 1995). The active ingredients of Azadirachta indica leaf trigger antibody responses and promote nonspecific defence mechanisms in fish (Venkatalakshmi \& Michael 2001). Both the aqueous and ethanolic herbal extracts of $A$. indica, Oscimum sanctum and Curcuma longa can limit the growth of Aeromonas hydrophila in vitro and promote innate immunity against this pathogen (Harikrishnan \& Balasundaram 2005, Harikrishnan et al. 2009). As a result, A. indica, $O$. sanctum and $C$. longa were selected for this study, all of which are cost effective and locally available. A number of probiotic preparations are commercially available and have been used in fish, shrimp, and molluscan farming as feed additives or incorporated in pond water (Wang et al. 2005). The aim of the present work was to assess the efficiency of dietary administration of 2 types of probiotics and a triherbal extract on haematological changes and innate immunity in common carp infected with A. hydrophila.

\section{MATERIALS AND METHODS}

Fish. Apparently healthy common carp Cyprinus carpio (mean weight: $52 \pm 2 \mathrm{~g}$ ), obtained from a local fish farm in Tiruchirapalli, Tamilnadu, India, were transported to the laboratory in plastic bags filled with oxygenated water. The fish were acclimatized in plastic aquaria $(60 \times 50 \times 70 \mathrm{~cm})$ containing $100 \mathrm{l}$ of water for $3 \mathrm{wk}$ under laboratory conditions (14 h light:10 h dark cycle). The observed water quality parameters were: dissolved oxygen concentration of 5.2 to $7.8 \mathrm{mg}$ $\mathrm{l}^{-1}$ (Winkler's method), $\mathrm{pH} 5.5$ to 7.1 and temperature of $28 \pm 2{ }^{\circ} \mathrm{C}$ during the whole trial. The fish in the control and infected untreated groups were fed ad libitum once daily with a formulated normal diet (without probiotics or triherbal extract). The treated groups were fed with a normal diet enriched with probiotics or triherbal extract at a rate of $2 \%$ of their body weight per day throughout the experiment (Table 1). Once every $5 \mathrm{~d}, 50 \%$ of the water in the aquaria was renewed to remove the uneaten and faecal material.

Aeromonas hydrophila. A. hydrophila (MTCC 646) was obtained from the Institute of Microbial Technology, Government of India, Chandigarh, and maintained in the laboratory under standard conditions (Harikrishnan et al. 2003). The identity of A. hydrophila was verified using biochemical tests, as described previously (Harikrishnan et al. 2010). Subcultures were maintained on tryptic soy agar (TSA; Himedia) on slopes at $5^{\circ} \mathrm{C}$ and routinely tested for pathogenesis (Joseph \& Carnahan 1994) by inoculation into American eels (Le Sueur) (Davis \& Hayasaka 1983). Stock culture in tryptic soy broth (TSB; Himedia) was stored at $-70^{\circ} \mathrm{C}$ in $0.85 \% \mathrm{NaCl}$ with $20 \%$ glycerol (v/v) to provide stable inoculate throughout the experiment (Chabot \& Thune 1991). Subcultures were taken from the TSA slope and harvested in TSB. The inoculated broth was incubated for $24 \mathrm{~h}$ in a shaker at $25^{\circ} \mathrm{C}$, and then centrifuged at $10000 \times g$ for $20 \mathrm{~min}$ at $4^{\circ} \mathrm{C}$ (Harikrishnan et al. 2003). The supernatant was discarded and the bacterial pellet was washed 3 times with phosphate-buffered saline (PBS) at pH 7.2 (Yadav et al. 1992).

Bacterial procurement, growth and harvest. The probiotic bacterial strains of Lactobacillus rhamnosus (Lactobacillus) and L. sporogenes (Sporolac) were obtained from Inter Care, Mehsana, Gujarat and UNISankyo, Ratnagiri, Maharashtra (Ahilan et al. 2004). The bacteria were cultured in MRS broth (De Man et al. 1960) for $48 \mathrm{~h}$ at $30^{\circ} \mathrm{C}$ and subsequently preserved in $50 \%$ glycerol at $-80^{\circ} \mathrm{C}$ and kept as stab cultures for 
further use. A pure colony was taken for inoculation of seed cultures of $50 \mathrm{ml}$ each and incubated at $30^{\circ} \mathrm{C}$ for $24 \mathrm{~h}$ before mass culture in MRS broth. After $1 \mathrm{~d}$ of culture, the bacteria were harvested by centrifuging at $16500 \times g$ for $10 \mathrm{~min}$ and washing 3 times with sterile peptone water $(0.85 \% \mathrm{NaCl}$ and $0.1 \%$ Polypeptone).

Supplementation of the standard diet with probiotics. The fish feed was prepared in the laboratory using soybean and fish meal as the protein source (Table 1). To enrich the normal diet with the probiotics, the required amount of bacterial suspension was sprayed into the feed slowly, mixing part by part in a drum mixer, after which it was air dried under sterile conditions for $12 \mathrm{~h}$. The viability of the incorporated bacterial cells was assessed by spreading onto triplicate plates of TSA (Becton, Dickinson), MRS agar (MERCK) and BA blood agar (Nissui). The colony count was taken after incubation at $30^{\circ} \mathrm{C}$ for $48 \mathrm{~h}$. The bacterial count of the feed was taken at this point and twice during the trial, and averaged $2.45 \times 10^{9}$ and $1.07 \times 10^{11} \mathrm{CFU} \mathrm{g}^{-1}$ for Lactobacillus and Sporolac, respectively. The pellets were dried in an oven at $30^{\circ} \mathrm{C}$ for $18 \mathrm{~h}$, packed and stored in a freezer at $-20^{\circ} \mathrm{C}$ until use. Before use in the feeding trial, bacterial counts confirmed the final concentration of live Lactobacillus and Sporolac in feed pellets to be $2.45 \times 10^{9}$ and $1.07 \times$ $10^{11} \mathrm{CFU} \mathrm{g}^{-1}$, respectively.

Preparation of herbal extract. Fresh leaves of neem Azadirachta indica, tulsi Oscimum sanctum and turmeric Curcuma longa were collected from the Bharathidasan University campus during May 2007. About $5 \mathrm{~kg}$ of each leaf were washed in sterile distilled water. The leaves were separately shade dried for $10 \mathrm{~d}$ until weight constancy was achieved. Each sample was finely powdered in an electric blender. C. longa, $O$. sanctum and $A$. indica leaf powders were evenly mixed at a ratio of $1: 1: 1$. The triherbal extract was made with $100 \mathrm{~g}$ of the mixed powder dissolved or soaked in $1000 \mathrm{ml}$ sterile distilled water in $2000 \mathrm{ml}$ conical flasks. Conical flasks were tightly covered with aluminium foil, kept for $7 \mathrm{~d}$ at room temperature and agitated daily. The extract was then filtered through sterile muslin cloth. The filtrate was collected and the solvent was evaporated using a rotary vacuum evaporator (Buchi SMP). The residue obtained after evaporation was mixed with the normal diet at $1000 \mathrm{mg} \mathrm{kg}^{-1}$ (w/v) (Harikrishnan et al. 2009).

Experimental design. Healthy common carp Cyprinus carpio (52 $\pm 2 \mathrm{~g}, \mathrm{n}=250)$ were inoculated intramuscularly $(50 \mu \mathrm{l})$ with Aeromonas hydrophila $(1.8 \times$ $10^{6} \mathrm{CFU} \mathrm{ml}{ }^{-1}$ ). Fish were anaesthetized with MS-222 (tricaine methanesulphonate, Sigma), 1:4000 in dechlorinated water, for 2 min (Ortuno et al. 2000). On Day 6 post-infection, the following treatments were applied: (1) control, without inoculum fed with normal $\operatorname{diet}(\mathrm{C}, \mathrm{n}=50)$; (2) inoculated fish, fed with normal diet (IU, $\mathrm{n}=50$ ); and inoculated fish treated with diets enriched with (3) triherbal extract $(\mathrm{H}, \mathrm{n}=50)$; (4) Lactobacillus ( $\mathrm{L}, \mathrm{n}=50)$; and (5) Sporolac ( $\mathrm{S}, \mathrm{n}=50$ ) in triplicate groups. Fish were fed daily to satiation by hand at 08:00 and 14:00 h.

Blood sampling for haematology and immunology. Sampling was carried out in Weeks 1, 2 and 4. Feeding was ceased for $24 \mathrm{~h}$ prior to sampling, after which 6 fish were selected randomly from each group. Individual fish were anaesthetized with MS-222 and approximately $0.5 \mathrm{ml}$ of blood was collected from the caudal vein of each using a $1 \mathrm{ml} 27$-gauge syringe needle fitted with a vacutainer (Sigma). One half of each blood sample was mixed with anticoagulant then stored at $4^{\circ} \mathrm{C}$ using EDTA serum tubes (BD vacutainer, Becton Dickinson), while the remainder was used immediately for haematological examination. Samples in serum tubes were placed at room temperature and allowed to clot for $2 \mathrm{~h}$. Sera were separated by centrifugation at $1500 \times g$ for $20 \mathrm{~min}$ and sera from the same groups were pooled before being stored at $-70^{\circ} \mathrm{C}$ for biochemical and immunological analyses. Red blood cells (RBC: $10^{6} \mathrm{~mm}^{-3}$ ) and white blood cells (WBC: $10^{4} \mathrm{~mm}^{-3}$ ) were counted manually by haemocytometry (Houston 1990) using a Neubauer haemocytometer after diluting blood samples by adding Hayem's solution for RBC and Türk's solution for WBC. Haemoglobin concentration ( $\mathrm{Hb}: \mathrm{g} \mathrm{dl}^{-1}$ ) was measured spectrophotometrically at $540 \mathrm{~nm}$ using the cyanmethemoglobin method (Drobkin 1945). The haematocrit (Ht: \%) was measured by the microcentrifuge method, using standard heparinised microhaematocrit capillary tubes $(75 \mathrm{~mm}$ at $7000 \times g$ for $10 \mathrm{~min})$. The mean corpuscular volume (MCV: $\mu^{3}$ ), mean corpuscular haemoglobin ( $\mathrm{MCH}$ : pg) and mean corpuscular haemoglobin concentration (MCHC: $\mathrm{g} \mathrm{dl}^{-1}$ ) of derived erythrocytes were calculated according to Houston (1990). The total protein (TP: $\mathrm{mg} \mathrm{dl}^{-1}$ ), glucose (GLU: $\mathrm{mg} \mathrm{dl}^{-1}$ ) and cholesterol (CHO: $\mathrm{mmol} \mathrm{dl}^{-1}$ ) were determined as described by Hawk et al. (1954).

Preparation of chemiluminescence reagents. Zymosan A (Sigma) was boiled and washed 3 times with Hanks' balanced salt solution (HBSS). A stock solution of $10 \mathrm{mg} \mathrm{ml}^{-1}$ was made in the same buffer and stored at $-70^{\circ} \mathrm{C}$ until required. Washed zymosan was opsonised with $25 \%$ rainbow trout sera diluted in HBSS, incubated for $25 \mathrm{~min}$ at room temperature and washed 3 times with HBSS. A $10 \mathrm{mM}$ stock solution of luminol (5-amino-2,3-dihydro-1,4-pthalazinedione, Sigma) was prepared in $0.2 \mathrm{M}$ sodium borate buffer, $\mathrm{pH} 9.0$, and stored at $-70^{\circ} \mathrm{C}$ until use.

Respiratory burst assay. The respiratory burst (RB) activity was determined according to the method of 
Lilius \& Waris (1984) and Marnila et al. (1995). The RB activity of phagocytes was measured as zymosaninduced, luminol-enhanced chemiluminescence (CL) emission in the diluted blood of the individual carp. Individual blood samples collected in EDTA tubes were diluted 1:400 in HBSS. The CL measurements were performed using $200 \mu$ l diluted blood, $50 \mu \mathrm{l}$ $10 \mathrm{mM}$ luminol in borate buffer, $\mathrm{pH} 9.0$, and $50 \mu \mathrm{l}$ opsonised zymosan (10 $\left.\mathrm{mg} \mathrm{ml}^{-1}\right)$, in a Wallac 1251 luminometer. The measurements were performed at $20^{\circ} \mathrm{C}$. The $\mathrm{CL}$ emission was measured for $80 \mathrm{~min}$ in order to obtain kinetic curves for each sample.

Complement-mediated killing. Complement-mediated killing was determined according to the method of Nikoskelainen et al. (2002). Escherichia coli MC1061 pEGFPLucAmp containing reporter genes for green fluorescent protein (GFP) and luciferase was grown in LB medium (1\% tryptone, $0.5 \%$ yeast extract, $0.5 \%$ $\mathrm{NaCl}_{i} \mathrm{pH} 7.0$ ) containing $100 \mu \mathrm{g} \mathrm{ml}^{-1}$ ampicillin at $37^{\circ} \mathrm{C}$ with agitation, to the mid logarithmic growth phase. The cells were harvested by centrifugation at $2500 \times g$ and washed twice with saline. The light absorption of the cell suspension was adjusted to $0.5 \pm$ 0.05 at $600 \mathrm{~nm}$, which equals $4 \times 10^{8} \mathrm{CFU} \mathrm{ml}{ }^{-1}$. The serum dilutions were prepared using heat-inactivated foetal calf serum (Fetal Clone ${ }^{2}$, HyClone Laboratories) by heating at $56^{\circ} \mathrm{C}$ for 30 min to keep the protein concentration equal in all samples. The complement reactions were carried out by mixing equal volumes of pooled carp serum (individual sera from the same group at each time point were pooled) and E. coli to obtain final serum concentrations of $0,3,6,9,12,15$, $17,20,25,30,35,50,100$, and $150 \mu \mathrm{ml}^{-1}$ and a bacterial concentration of $2 \times 10^{8} \mathrm{CFU} \mathrm{ml}^{-1}$. Reaction mixtures were incubated for $90 \mathrm{~min}$ at $20^{\circ} \mathrm{C}$. The reaction was stopped by placing the sample tubes in ice for $10 \mathrm{~min}$. The viability of $E$. coli in the reaction mixtures was determined by placing $100 \mu \mathrm{l}$ into microtiterplate wells (White Cliniplate, Labsystems) and adding $100 \mu \mathrm{l}$ $0.5 \mathrm{mM}$ D-luciferin in citrate buffer, $\mathrm{pH}$ 5. The luminescence of viable $E$. coli was measured with an Ascent FLII fluoro-luminometer (Labsystems). The luminescence data were converted to \% viability, assuming that the bacterial viability was $100 \%$ when the active serum concentration was $0 \mu \mathrm{ml}^{-1}$. The $\%$ viability was then plotted as a function of the active serum concentration $\left(\mu \mathrm{l} \mathrm{ml}^{-1}\right)$ in Origin (MicroCal). The unit of complement ( $\mu$ l of the active serum that kills $50 \%$ of the bacteria) was obtained from the plot and the CB50 value was calculated as units $\mathrm{ml}^{-1}$ of active serum.

Disease resistance. Aeromonas hydrophila (MTCC 646) was inoculated into TSB at $28^{\circ} \mathrm{C}$. The culture was centrifuged at $800 \times g$ for $15 \mathrm{~min}$ at $4^{\circ} \mathrm{C}$. The packed cells were washed and the required dose was prepared in PBS. On Day 1, fish were challenged with $50 \mu$ l of $A$. hydrophila $\left(1.8 \times 10^{6} \mathrm{CFU} \mathrm{ml}{ }^{-1}\right)$ intraperitoneally. On Day 6 post-infection, groups of 10 fish, each in triplicate, were adminitered with $\mathrm{H}, \mathrm{S}$ and $\mathrm{L}$ diets. The control and IU fish were administered normal diets. In our previous study, the fish challenge dose was standardized to give $85 \%$ mortality in the untreated group (Harikrishnan et al. 2009). Mortality was recorded on daily basis for $30 \mathrm{~d}$. The relative percent survival (RPS) was calculated using the following formula (Amend 1981):

RPS $=1-\frac{\text { (Percent mortality in treated group })}{\text { (Percent mortality in control group })} \times 100$ (Percent mortality in control group)

Statistics. All results are presented as the average and standard deviation of 3 independent measurements. The nonparametric ANOVA (SPSS computer programme) was used to determine whether there was a significant difference $(p<0.05)$ in the haematological and immunological parameters between control and tested groups.

\section{RESULTS}

\section{Haematological profile}

The WBC levels were significantly higher $(\mathrm{p}<0.05)$ in all the experimental groups in Weeks 1 to 4 when compared to the control. The RBC values were significantly lower $(\mathrm{p}<0.05)$ than the control values in all the experimental groups throughout the experimental period. The $\mathrm{Hb}$ concentrations of the IU and $\mathrm{H}$ groups were significantly lower than that of the control. There was no change in the $\mathrm{Hb}$ level of the infected groups fed with the $\mathrm{S}$ and $\mathrm{L}$ diets between Weeks 1 and 4 . The Ht was significantly lower in IU and $\mathrm{H}$ diet groups. However, in the S and L groups, the Ht values did not differ in any sampling week. The MCV was significantly increased in all the experimental groups in Weeks 2 and 4 when compared to the control. However, there was no change in the MCV in the first week. The $\mathrm{MCH}$ was significantly increased in Weeks 1 and 2 in all the experimental groups. However, the MCHC values did not show a significant change $(p>0.05)$ in all of the experimental groups compared to control (Fig. 1).

\section{Biochemical profile}

In all the diet groups, the TP levels did not change in the first week when compared to the control. In the $\mathrm{H}$ and $\mathrm{S}$ groups, the TP level was significantly decreased in Week 2, after which it was restored to a level near that of the control in Week 4. In the L group, the TP level did not change from Week 2 to 4 . The GLU and 

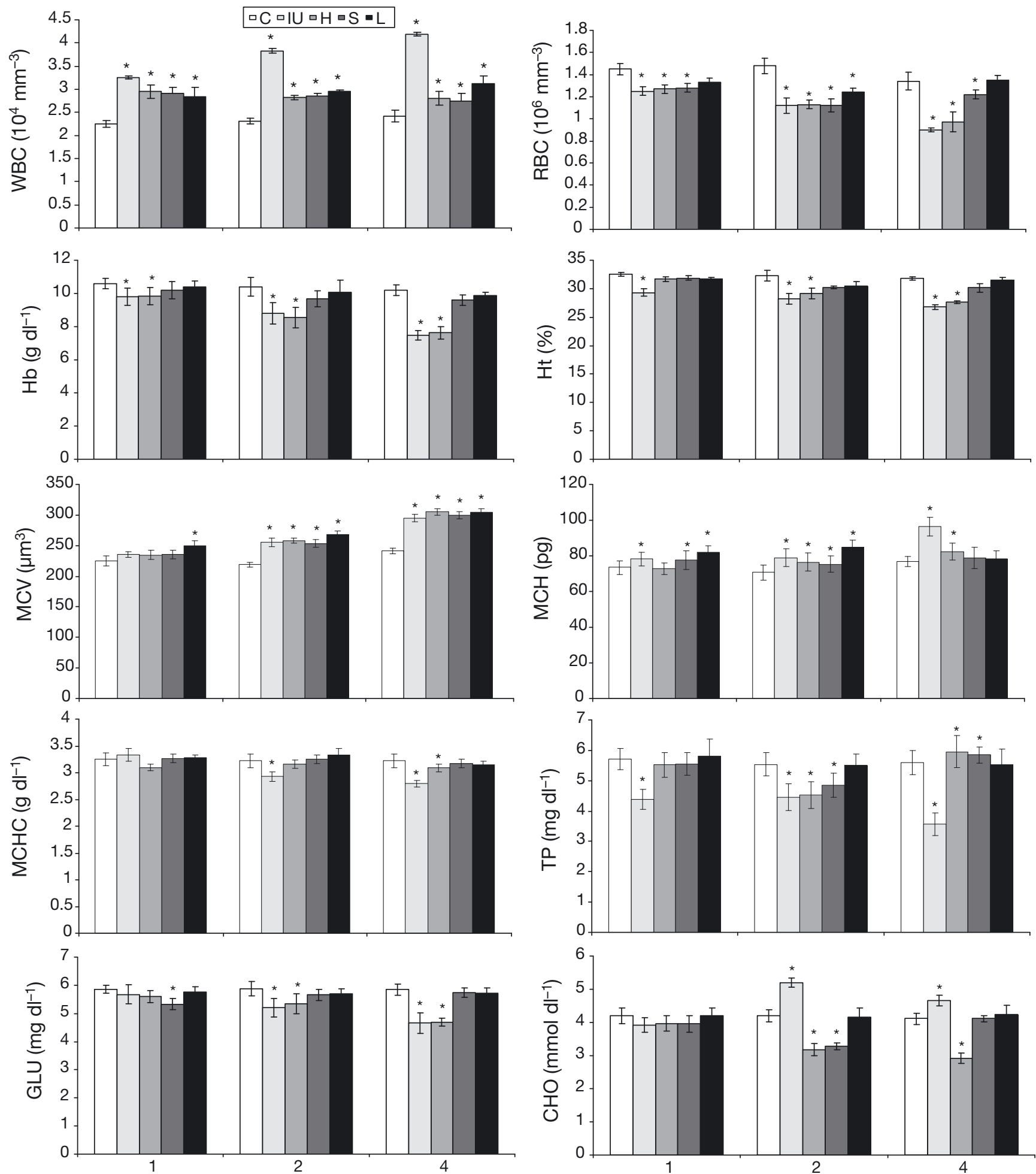

Week post treatment

Fig. 1. Cyprinus carpio infected with Aeromonas hydrophila. Changes in haematological and biochemical profile of different experimental groups ( $\mathrm{n}=6$ in each group). C: Control, fed with normal diet, IU: infected, fed with normal diet, H: infected, fed with triherbal extract-enriched diet, S: infected, fed with Sporolac-enriched diet, L: infected, fed with Lactobacillus-enriched diet, WBC: white blood cells, RBC: red blood cells, Hb: haemoglobin, Ht: haematocrit, MCV: mean corpuscular volume, MCH: mean corpuscular haemoglobin, MCHC: mean corpuscular haemoglobin concentration, TP: total protein, GLU: glucose, CHO: cholesterol. *Statistically significant difference $(p<0.05)$ compared to the control group in the same sampling week 
CHO levels of the S and L groups were similar to those of the control group throughout the experimental period. However, in the IU and $\mathrm{H}$ groups, the GLU significantly decreased, whereas in the IU group the $\mathrm{CHO}$ level was significantly increased in Weeks 2 and 4 (Fig. 1).

\section{Respiratory burst activity}

In all the treated groups, respiratory activity did not vary significantly while it increased in the L group in Week 1. In the H, S, and L groups, it increased significantly in Weeks 2 and 4 . In the IU group, the respiratory burst activity was significantly decreased in all weeks when compared to the control (Fig. 2).

\section{Serum bactericidal activity}

The complement activity of common carp serum against Escherichia coli at $20^{\circ} \mathrm{C}$ was enhanced in the $\mathrm{S}$ and L groups in Week 4. Fish in the $\mathrm{H}$ group had no increased complement activity in any sampling week when compared to the control. However, the IU group had a significantly lower complement activity (Fig. 3).

\section{Disease resistance}

Maximum protection was found in the group fed with the L diet. This group had the lowest mortality (35\%) and highest RPS. However, the cumulative mor-

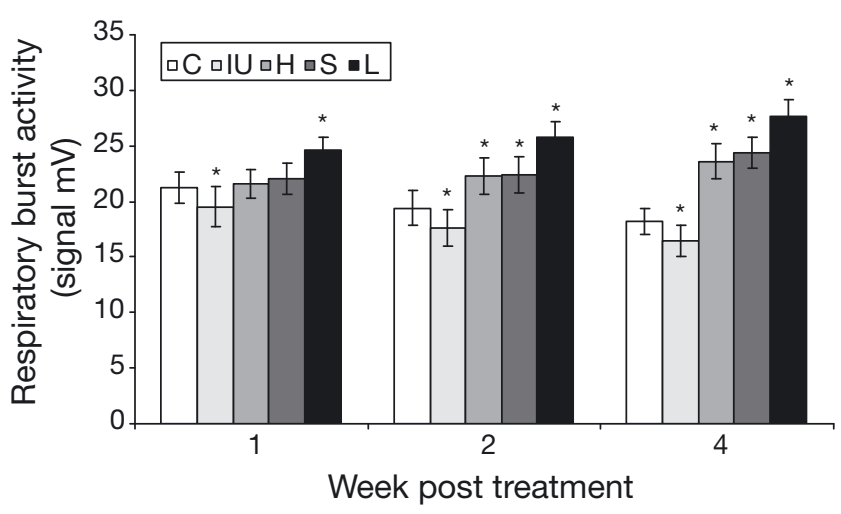

Fig. 2. Cyprinus carpio infected with Aeromonas hydrophila. Changes in respiratory burst (RB) activity measured in the diluted blood of the fish as zymosan-induced, luminolenhanced chemiluminescence (CL) emission in control (C), infected, untreated (IU) and infected fish fed with triherbal extract $(\mathrm{H})$ - or probiotic (S or L)-enriched diets. * Statistically significant difference $(\mathrm{p}<0.05)$ compared to the control group in the same sampling week

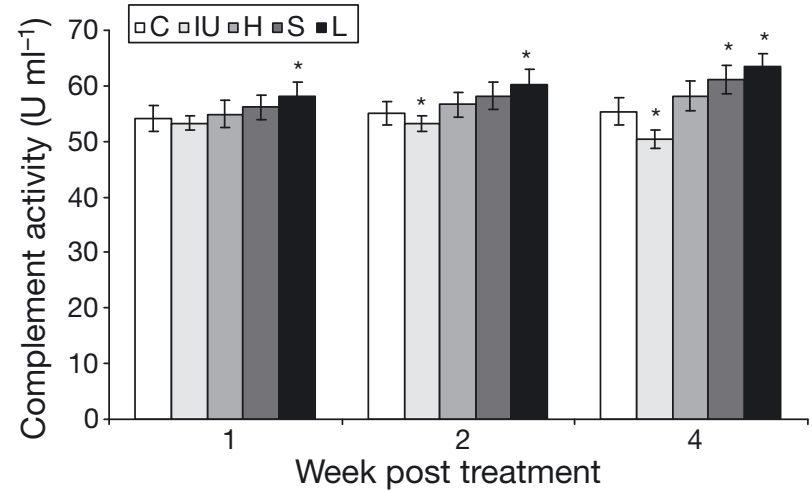

Fig. 3. Cyprinus carpio infected with Aeromonas hydrophila. Changes in complement activity measured as D-luciferinenhanced luminescence after 90 min incubation in control (C), infected, untreated (IU) and infected fish fed with triherbal extract $(\mathrm{H})$ - or probiotic (S or L)-enriched diets. *Statistically significant difference $(\mathrm{p}<0.05)$ compared to the control group in the same sampling week

tality was high in fish fed with the $\mathrm{H}$ and $\mathrm{S}$ diets, being $50 \%$ and $40 \%$, respectively, after $30 \mathrm{~d}$. The IU group had the maximum mortality $(85 \%)$, while there was no mortality in the control group (Fig. 4).

\section{DISCUSSION}

In this study, the WBC levels of infected untreated carp increased significantly from Week 1 to 4 . In the infected groups treated with the Sporolac (S)- and Lactobacillus (L)-enriched diets, the WBC levels were significantly increased compared to control values by Week 4, indicating suppression of the growth of the pathogen. However, the RBC levels in all groups except the L group were significantly decreased compared to control in all weeks. Monitoring these values and profiling leucocytes provides information about the general immune status of the fish. In our study, RBC levels, $\mathrm{Hb}$ and $\mathrm{Ht}$ declined significantly in the infected, untreated group, indicating the destruction of RBCs leading to anaemia (Haney et al. 1992, Denton \& Yousef 1975). Such reductions have been confirmed in yellowtail flounder Limanda ferruginea (Allen et al. 2003) infected with various pathogens. Ht is the proportion of blood volume occupied by RBCs. In common catfish, $\mathrm{Hb}$ content has been shown to decrease due to the swelling of RBCs and poor mobilization of $\mathrm{Hb}$ from the spleen and other haematopoietic organs (Scott \& Rogers 1981). Low levels of RBC, Hb, Ht, MCV, MCH and $\mathrm{MCHC}$ have been reported in rainbow trout (Rehulka 1998) and goldfish (Brenden \& Huizinga 1986) in response to Aeromonas hydrophila infection 


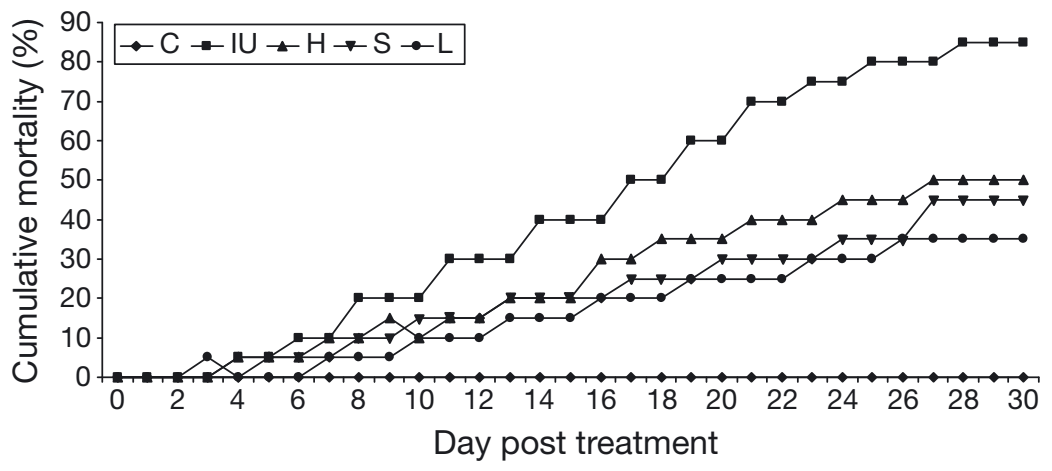

Fig. 4. Cyprinus carpio infected with Aeromonas hydrophila. Percentage of cumulative mortality in control (C), infected, untreated (IU) and infected fish fed with triherbal extract $(\mathrm{H})$ - or probiotic (S or L)-enriched diets over $30 \mathrm{~d}$ carp. It has been shown that certain probiotic bacteria and triherbal extracts are able to stimulate phagocytic activity (Arunachalam et al. 2000, Schiffrin et al. 1997, Harikrishnan et al. 2009) as well as complement receptor expression (Pelto et al. 1998). Respiratory burst activity correlates well with phagocytosis of bacteria in fish (Hardie et al. 1996, Neumann et al. 2001) as well as in humans (Loimaranta et al. 1999). The chemiluminescence-based respiratory burst assay is, therefore, a rapid method for analysing phagocytic activity (Lilius \& Waris 1984). The present study demonstrates that oral administration of and epizootic ulcerative syndrome (EUS). Hb content is related to the growth and volume of RBCs (Houston 1990).

In our study, $\mathrm{RBC}$ and $\mathrm{Hb}$ values in fish fed with the $\mathrm{L}$ diet were close to those of the control. Groups of lactic acid bacteria exhibit inhibitory activities against Gram-positive and Gram-negative fish pathogens in vitro (Jöborn et al. 1997, Nikoskelainen et al. 2003) and Lactobacillus acidophilus has been shown to induce inhibition zones in Aeromonas hydrophila and Streptococcus iniae (Aly et al. 2008). Similar correlations have also been reported with the use of lactic acid bacteria as probiotics in Vibrio anguillarum and A. salmonicida (Gildberg et al. 1995). The general concept that the use of probiotics in aquaculture may produce various beneficial effects has been proven beyond doubt (Gatesoupe 1999, Balcázar et al. 2006). The aqueous extract of Azadirachta indica and other herbals has been shown to restored the altered haematological and biochemical parameters healing the lesions in Cyprinus carpio and Labeo rohita caused by either Aeromonas or Aphanomyces infections (Mitra \& Varshney 1994, Harikrishnan et al. 2003, 2005).

Our results showed that the total protein and glucose levels in the IU group decreased while the cholesterol level increased throughout the experimental period. Similar trends have been reported in Atlantic salmon infected with Vibrio (Waagbo et al. 1988), and in rainbow trout infected with haematopoietic necrosis virus (Amend \& Smith 1975). Haney et al. (1992) found that the total plasma protein and glucose levels increased in fish fed with probiotics-enriched diets due to the destruction of RBCs and the resultant release of cell contents into the blood stream.

In the present study, the respiratory burst activity in the probiotics and herbal extract diet groups $(\mathrm{H}, \mathrm{S}$ and L) increased throughout the experimental period. This shows that the probiotic diet increases respiratory burst activity and complement activity in common
Lactobacillus and Sporolac stimulated respiratory burst activity within $2 \mathrm{wk}$.

Oral administration of probiotic bacteria at an optimal dose (from $10^{4} \mathrm{CFU} \mathrm{g}^{-1}$ to $10^{8} \mathrm{CFU} \mathrm{g}^{-1}$ of feed) has been shown to stimulate respiratory burst activity augmenting the protective mechanism (Nikoskelainen et al. 2001), and to induce cell-mediated immunity by stimulating cytokine production in fish as well as in mammals (Miettinen et al. 1996). In humans, probiotic bacteria are known to stimulate antibody production (Malin et al. 1996). In the present study, the complement bactericidal activity increased significantly in Weeks 2 and 4 in the Lactobacillus and Sporolac diet groups. However, the mechanism of the effect of probiotic bacteria on this activity is unclear.

In a previous study, it was demonstrated that oral administration of Lactobacillus rhamnosus could reduce mortality of fish challenged with a virulent strain of Aeromonas salmonicida (Nikoskelainen et al. 2001). The best protection against $A$. salmonicida was observed when fish were treated with a Lactobacillusenriched diet (mortality 35\%). Moreover, in that study, higher protection was observed in fish treated with a Sporolac-enriched diet (mortality 45\%) followed by those receiving a triherbal extract-enriched diet (mortality 50\%) compared to the infected, untreated group (mortality 85\%). A higher dose of Lactobacillus (1.9 to $9.7 \times 10^{10} \mathrm{CFU} \mathrm{g}^{-1}$ ) in feed did not increase the respiratory burst activity. Furthermore, it is known that virulent strains of fish pathogens like $A$. salmonicida can resist both the cellular (Daly et al. 1996, Barnes et al. 1999) and humoral defences (Merino et al. 1994, 1997) of fish but they can be killed by activated macrophages.

We have shown that probiotic treatment is can restore altered haematological and biochemical parameters to near normal values. The present work shows that the chosen probiotic bacteria might have an impact on the specific and innate immunity of fish. 
They may also trigger the immune system of Tilapia Oreochromis mossambicus infected with Aeromonas hydrophila (Venkatalakshmi \& Michael 2001, Nikoskelainen et al. 2003). It can be concluded that the probiotic-enriched diet is more effective than the triherbal extract-enriched diet, and that Lactobacillus was superior to Sporolac in affording protection against pathogens and promoting survival. Further extensive testing, including field and commercial cost benefit analysis, is necessary before recommending its widespread application in aquaculture. The optimal dose of the probiotic bacteria to be administered may depend on the size and species of cultivated fish.

Acknowledgements. R.H. is grateful to the Council of Scientific and Industrial Research (CSIR), India for the award of Research Associateship, and the financial assistance through a KOSEF Postdoctoral Fellowship and the BK 21 programme of the Ministry of Education, South Korea, which made this work possible. All authors are grateful to the Department of Science and Technology, for the facilities provided to the department through the FIST program and UGC-SAP.

\section{LITERATURE CITED}

Ahilan B, Shine G, Santhanam R (2004) Influence of probiotics on the growth and gut microbial load of juvenile goldfish (Carassius auratus). Asian Fish Sci 17:271-278

Allen RM, Dawson MA, Kuropat CA, Kapareiko D (2003) Variability in blood chemistry of yellowtail flounder, Limanda ferruginea, with regard to sex, season, and geographic location. National Oceanic and Atmospheric Administration, Technical Memorandum, NMFS-NE-180

Aly SM, Ahmed YAG, Ghareeb AAA, Mohamed MF (2008) Studies on Bacillus subtilis and Lactobacillus acidophilus, as potential probiotics, on the immune response and resistance of Tilapia nilotica (Oreochromis niloticus) to challenge infections. Fish Shellfish Immunol 25:128-136

Amend DF (1981) Potency testing of fish vaccines. Dev Biol Stand 49:447-454

Amend DF, Smith L (1975) Pathophysiology of infectious hematopoietic necrosis virus disease in rainbow trout (Salmo gairdneri): early changes in blood and aspects of the immune response after injection of IHV virus. J Fish Res Board Can 31:1371-1378

Anderson DP (1992) Immunostimulants, adjuvants and vaccine carriers in fish: applications to aquaculture. Annu Rev Fish Dis 2:281-307

Arunachalam K, Gill HS, Chandra RK (2000) Enhancement of natural immune function by dietary consumption of Bifidobacterium lactis (HN019). Eur J Clin Nutr 54:263-267

Austin B, Austin DA (1993) Bacterial fish pathogens: disease in farmed and wild fish. Ellis Horwood, New York, NY

Balcázar JL, de Blas I, Ruiz-Zarzuela I, Cunningham D, Vendrell D, Múzquiz JL (2006) The role of probiotics in aquaculture. Vet Microbiol 114:173-186

Barnes AC, Bowden TJ, Horne MT, Ellis AE (1999) Peroxideinducible catalase in Aeromonas salmonicida subsp. salmonicida protects against exogenous hydrogen peroxide and killing by activated rainbow trout, Oncorhynchus mykiss L., macrophages. Microb Pathog 26:149-158

Brenden RA, Huizinga HW (1986) Pathophysiology of experimental Aeromonas hydrophila infection in goldfish (Carassius auratus). J Fish Dis 9:163-167
Chabot DJ, Thune RL (1991) Proteases of the Aeromonas hydrophila complex: identification, characterization and relation to virulence in channel catfish, Ictalurus punctatus (Rafinnesque). J Fish Dis 14:171-183

Chen CY, Wooster GA, Geetchell RG, Bowser PR, Timmons MB (2003) Blood chemistry of healthy, nephrocalcinoseisaffected and ozone-treated tilapia in a recirculation system, with application of discriminant analysis. Aquaculture 218:89-102

Daly JG, Kew AK, Moore AR, Olivier G (1996) The cell surface of Aeromonas salmonicida determines in vitro survival in cultured brook trout (Salvelinus fontinalis) peritoneal macrophages. Microb Pathog 21:447-461

Davis JF, Hayasaka SS (1983) Pathogenic bacteria associated with cultured American eels Anguilla rostrata Le Sueur. J Fish Dis 23:557-564

De Man JC, Rogosa M, Sharpe ME (1960) A medium for the cultivation of lactobacilli. J Appl Bacteriol 23:130-135

Denton JE, Yousef MK (1975) Seasonal changes in hematology of rainbow trout, Salmo gairdneri. Comp Biochem Physiol 51:151-153

Drobkin DR (1945) Crystallographic and optical properties of human hemoglobin: A proposal for the standardization of hemoglobin. Am J Med Sci 209:268-270

> Gatesoupe FJ (1999) The use of probiotics in aquaculture. Aquaculture 180:147-165

Gibson GR, Saavendra JM, Macfarlane S, Macfarlane GT (1997) Probiotics and intestinal infections. In: Fuller R (ed) Probiotics 2: applications and practical aspects. Chapman \& Hall, London, $\mathrm{p}$ 133-161

> Gildberg A, Johansen A, Bogwald J (1995) Growth and survival of Atlantic salmon (Salmo salar) fry given diets supplemented with fish protein hydrolysate and lactic acid bacteria during a challenge trial with Aeromonas salmonicida. Aquaculture 138:23-34

> Haney DC, Hursh DA, Mix MC, Winton JR (1992) Physiological and hematological changes in chum salmon artificially infected with erythrocytic necrosis virus. J Aquat Anim Health 4:48-57

Hardie LJ, Ellis AE, Secombes CJ (1996) In vitro activation of rainbow trout macrophages stimulates inhibition of Renibacterium salmoninarum growth concomitant with augmented generation of respiratory burst products. Dis Aquat Org 25:175-183

Harikrishnan R, Balasundaram C (2005) Antimicrobial activity of medicinal herbs in vitro against fish pathogen, Aeromonas hydrophila. Fish Pathol 40:187-189

> Harikrishnan R, Nisha Rani M, Balasundaram C (2003) Hematological and biochemical parameters in common carp, Cyprinus carpio, following herbal treatment for Aeromonas hydrophila infection. Aquaculture 221: $41-50$

> Harikrishnan R, Balasundaran C, Bhuvaneswari R (2005) Restorative effect of Azadirachta indica aqueous leaf extract dip treatment on haematological parameter changes in Cyprinus carpio (L.) experimentally infected with Aphanomyces invadans fungus. J Appl Ichthyology 21:410-414

> Harikrishnan R, Balasundaram C, Kim MC, Kim JS, Han YJ, Heo MS (2009) Innate immune response and disease resistance in Carassius auratus by triherbal solvent extracts. Fish Shellfish Immunol 27:508-515

Harikrishnan R, Balasundaram C, Moon YG, Kim MC, Kim JS, Dharaneedharan S, Heo MS (2010) Phytotherapy of ulcerative dermatitis induced by Aeromonas hydrophila infection in goldfish (Carassius auratus). Acta Vet Hung 58:29-37 
Hawk PB, Oser BL, Summersion WH (1954) Practical physiological chemistry. McGraw-Hill, New York, NY

Houston AH (1990) Blood and circulation. In: Schreck CB, Moyle PB (eds) Methods in fish biology. American Fisheries Society, Bethesda, MD, p 273-335

Jöborn A, Olsson JC, Westerdahl A, Conway PL, Kjelleberg S (1997) Colonization in the fish intestinal tract and production of inhibitory substances in intestinal mucus and faecal extracts by Carnobacterium sp. strain K1. J Fish Dis 20: 383-392

Joseph SW, Carnahan A (1994) The isolation, identification, and systematics of the motile Aeromonas species. Annu Rev Fish Dis 4:315-343

Klaenhammer TR (1988) Bacteriocins of lactic acid bacteria. Biochimie 70:337-349

- Leung KY, Low KW, Lam TJ, Sin YM (1995) Interaction of the fish pathogen Aeromonas hydrophila with tilapia, Oreochromis aureus (Steindachner), phagocytes. J Fish Dis 18:435-447

Lewus CB, Kaiser A, Montville DJ (1991) Inhibition of foodborne bacterial pathogens by bacteriocins from lactic acid bacteria isolated from meat. Appl Environ Microbiol 57:1683-1688

Lilius EM, Waris M (1984) A very sensitive and rapid chemiluminescence method for the measurement of phagocytosis. In: Kricka RC, Stanley PG, Thorpe GH, Whitehead TP (eds) Analytical application of bioluminance and chemiluminescence. Academic Press, Orlando, FL, p 401-404

Loimaranta V, Nuutila J, Marnila P, Tenovuo J, Korhonen H, Lilius EM (1999) Colostral proteins from cows immunised with Streptococcus mutans/S. sobrinus support the phagocytosis and killing of mutans streptococci by human leucocytes. J Med Microbiol 48:917-926

Malin M, Suomalainen H, Saxelin M, Isolauri E (1996) Promotion of IgA immune response in patients with Crohn's disease by oral bacteriotherapy with Lactobacillus GG. Ann Nutr Metab 40:137-145

Marnila P, Tiiska A, Lagerspetz K, Lilius EM (1995) Phagocyte activity in the frog Rana temporaria: whole blood chemiluminescence method and the effects of temperature and thermal acclimation. Comp Biochem Physiol 111:609-614

Merino S, Alberti S, Tomas JM (1994) Aeromonas salmonicida resistance to complement-mediated killing. Infect Immun 62:5483-5490

Merino S, Aguilar A, Tomas JM, Bonet R, Martinez MJ, Simon-Pujol D, Congregado F (1997) Complement resistance of capsulated strains of Aeromonas salmonicida. Microb Pathog 22:315-320

Miettinen M, Vuopio-Varkila J, Varkila K (1996) Production of human tumor necrosis factor alpha, interleukin-6, and interleukin-10 is induced by lactic acid bacteria. Infect Immun 64:5403-5405

Mitra SD, Varshney PK (1994) Use of Homeo drug for curing ulcerative syndrome in fishes. J Indian Fish Assoc 21: $55-56$

Neumann NF, Stafford JL, Barreda D, Ainsworth AJ, Belosevic M (2001) Antimicrobial mechanisms of fish phagocytes and their role in host defense. Dev Comp Immunol 25: $807-825$

Editorial responsibility: David Bruno,

Aberdeen, UK
Nikoskelainen S, Ouwehand AC, Bylund G, Salminen S (2001) Protection of rainbow trout (Oncorhynchus mykiss) from furunculosis by Lactobacillus rhamnosus. Aquaculture 198:229-236

Nikoskelainen S, Lehtinen J, Lilius EM (2002) Bacteriolytic activity of rainbow trout (Oncorhynchus mykiss) complement. Dev Comp Immunol 26:797-804

Nikoskelainen S, Ouwehand A, Bylund G, Salminen S, Lilius EM (2003) Immune enhancement in rainbow trout (Oncorhynchus mykiss) by potential probiotic bacteria (Lactobacillus rhamnosus). Fish Shellfish Immunol 15: 443-452

Ortuno J, Esteban MA, Meseduer J (2000) High dietary intake of $\alpha$-tocopherol acetate enhances the non-specific immune response of gilthead seabream (Sparus auratus L.). Fish Shellfish Immunol 10:293-307

Pelto L, Isolauri E, Lilius EM, Nuutila J, Salminen S (1998) Probiotic bacteria down-regulate the milk-induced inflammatory response in milk-hypersensitive subjects but have an immunostimulatory effect in healthy subjects. Clin Exp Allergy 28:1474-1479

Rehulka J (1998) Blood indices of the rainbow trout, Oncorhynchus mykiss (Walbaum) in Aeromonas-induced ulcerous dermatitis. Acta Vet (Brno) 67:317-322

Ringø E, Birkbeck TH (1999) Intestinal microflora of fish larvae and fry. Aquacult Res 30:73-93

Santos Y, Bandin I, Toranzo AE (1996) Immunological analysis of extracellular products and cell surface components of motile Aeromonas isolated from fish. J Appl Bacteriol 81:585-593

Schiffrin EJ, Brassart D, Servin AL, Rochat F, Donnet-Hughes A (1997) Immune modulation of blood leukocytes in humans by lactic acid bacteria: criteria for strain selection. Am J Clin Nutr 66:515-520

Scott AL, Rogers WA (1981) Hematological effects of prolonged sublethal hypoxia on channel catfish Ictalurus punctatus (Rafinesque). J Fish Biol 18:591-601

Sharifuzzaman SM, Austin B (2009) Influence of probiotic feeding duration on disease resistance and immune parameters in rainbow trout. Fish Shellfish Immunol 27: $440-445$

Skjermo J, Vadstein O (1999) Techniques for microbial control in the intensive rearing of marine larvae. Aquaculture 177:333-343

Vaidyaratnam PSV (1995) Indian medicinal plants. A compendium of 500 species, Vol 3-4. Orient Longman, Madras

Venkatalakshmi S, Michael RD (2001) Immunostimulation by leaf extract of Ocimum sanctum Linn. in Oreochromis mossambicus (Peters). J Aquacult Trop 16:1-10

Waagbo R, Sandnes K, Espelid S, Lie G (1988) Haematological and biochemical analyses of Atlantic salmon, Salmo salar L., suffering from coldwater vibriosis ('Hitra disease'). J Fish Dis 11:417-423

Wang YB, Xu ZR, Xia MS (2005) The effectiveness of commercial probiotics in northern white shrimp (Penaeus vannamei L.) ponds. Fish Sci 71:1034-1039

- Yadav M, Indira G, Ansary A (1992) Cytotoxin elaboration by Aeromonas hydrophila isolated from fish with epizootic ulcerative syndrome. J Fish Dis 15:183-189

Submitted: September 28, 2009; Accepted: May 6, 2010

Proofs received from author(s): September 27, 2010 